\title{
Comparative Analysis of Indigenous Knowledge (3) on Use and Management of Wild Edible Plants: The case of Central East Shewa of Ethiopia
}

Research

\author{
Debela Hunde Feyssa, Jesse T. Njoka, \\ Zemede Asfaw and M.M. Nyangito
}

\begin{abstract}
Quantitative ethnobotanical analysis of indigenous use and management practices of wild edible plants (WEPs) by transhumant and settled farmers was conducted to compare WEPs and associated indigenous knowledge (IK). Household interviews, key informant discussions, focus group discussions, field explorations and multistage direct matrix rankings were carried out to identify WEPs in six study sites of two districts in semiarid East Shewa, Ethiopia. Participant observations were made to identify local strategies of management of WEPs. The results showed that from 40 WEPs, $35(87.5 \%)$ of them were also used for forage/fodder, and 37 (92.5\%) for fuel wood. Forest is a common habitat for collection of these plants. Jaccard's Similarity Coefficient of the three use categories were $44.2 \%, 46.9 \%$ and $45.6 \%$ respectively. No gender differentiation was observed regarding their knowledge of habitats of WEPs collection. $42.2 \%$ of transhumant informants attested that intergenerational transfer of IK is the responsibility of the entire community while in the case of settled farmers this is left to fathers and mothers $(23.3 \%)$. There were significant variations in transferring IK $(P<0.05)$ between the two communities. Transhumants conserve WEPs in pasture land and protect vegetation while settled farmers employ traditional dryland agroforestry, living fences and farm boarders. Study communities have significant variation in their preference for WEPs $(P<0.05)$. The people showed greater preferences for five WEPs. The prioritized WEPs and associated IK and practices should be considered in planning conservation and sustainable use of WEPs by integrating the variations and complementing with appropriate modern practices.
\end{abstract}

\section{Introduction}

Indigenous knowledge on use of wild edible plants

Biodiversity includes wild food sources of many types including wild edible plants (WEPs). The uses and management of WEPs are variable with land use type and cultural variations within small scale landscapes. The contribution of wild plants in subsistence agriculture as food supplements and as a means of survival during times of drought and famine has been underestimated (Addis et al. 2005). This may be true in the case of Ethiopia, a country that encompasses two of the global biodiversity hot-spots and is known as a center of origin (Vavilovian Center) for a number of food plants (Schery 1972, Tadesse \& Alem 2009).

Elders and other knowledgeable community members are the key reservoirs of plant lore. Among the most common wild plant fruits consumed by Ethiopian children are Fi-

\section{Correspondence}

Debela Hunde Feyssa, Department of Natural Resource Management, College of Agriculture and Veterinary Medicine, Jimma University, ETHIOPIA.

feyssahunde@yahoo.com, feyssahunde@gmail.com

Jesse T. Njoka and M.M. Nyangito, Department of Land Resources \& Agricultural Technology, College of Agriculture \& Veterinary Sciences, University of Nairobi, KENYA jtnjoka@gmail.com; mmnyangito@yahoo.com

Zemede Asfaw, Department of Biology, College of Natural Sciences, Addis Ababa University, ETHIOPIA.

zemede@bio.aau.edu.et, zasfaw49@yahoo.com

Ethnobotany Research \& Applications 10:287-304 (2012)

Published: July 16, 2012

www.ethnobotanyjournal.org/vol10/i1547-3465-10-287.pdf 
cus spp, and Carissa spinarium L. (Gemedo-Dalle et al. 2005). In spite of some clues to their current contribution to food security of rural people, WEP resources, culture, traditions, and indigenous knowledge (IK) associated with the plants, still lacks adequate attention by development polices in Ethiopia (Balemie et al. 2006, Gemedo-Dalle et al. 2005).

There has been increased global awareness of the conservation of biodiversity following the United Nations Conference on Environment and Development held in June 1992 in Rio de Janeiro. Of equal concern is the fate of the multigenerational IK of ethnic groups across the globe, including their life experiences and problem solving strategies (Garcia 2009). Very little of this knowledge has been recorded, yet it is providing several communities knowledge of interacting with changing environments and ecosystem functions (Johns \& Eyzaguirre 2002). However, changes in food habits and lifestyles tend to marginalize and heighten the threats to wild species.

Sustainable management of ecosystems and biodiversity can be found in indigenous and local communities (Johns \& Eyzaguirre 2002). Studies have indicated that, communities in Africa and other parts of the world have played active roles in generating knowledge of their environment and conserving natural resources (Warren 1992, 1997). Though there is a good beginning in Ethiopia, the rate of implementation is low with little input to livelihoods of the people. The documentation and utilization of IK on use and management of WEPs is an outstanding research gap in the study districts.

The Global Biodiversity Strategy in its principles revealed that cultural diversity is closely linked to biodiversity and its associated ecosystems as a whole (Tauli-Corpuz 2010, Warren 1992). The use and management of WEPs as essential components of ecosystems are also part of the biocultural diversity of each country. Humanity's knowledge of biodiversity, its use and management rests in cultural diversity. Conserving biodiversity helps to strengthen cultural integrity (Gemedo-Dalle et al. 2005, Maffi 2005). Hence, studies that depict local communities and their knowledge as primitive, simple and static must be countered by generating data that describes indigenous resource management practices related to WEPs. Ethiopia's WEPs and associated IK must be addressed in this regard (Asfaw 2009).

Studies have shown that ethnobotanical knowledge of natural resource management is greater than previously assumed. These studies may guide new ways for development that are ecologically and socially sound (Gemedo-Dalle et al. 2005). Ethnobotanical knowledge of use and management of WEPs varies depending on specific landscapes, vegetation, and lifestyles of people in Ethiopia with greater variability occurring in arid and semi-arid areas (Asfaw 2009).
In Ethiopia, consumption of WEPs is an important local survival strategy, made necessary by climatic fluctuations which hamper agricultural efforts (Gemedo-Dalle et al. 2005). Increased consumption of WEPs enables people to cope better with erratic weather, untimely rains, and seasonal droughts (Mathys 2000, Wube 2009). Balamie and Kebebew (2006) and Guinand and Lemessa (2000) reported that, people in southern Ethiopia, Konso, Derashe and Burji districts still use a diversity of WEPs. Few specifics have been documented and this leads to greater concern when looking at the frequency of recent food shortages in Ethiopia and the extent to which subsistence agriculture is still the norm. Therefore, the purpose of the present study was to identify the diversity of indigenous use and management of WEPs and implications for conservation of WEPs and food security in semiarid East Shewa, Ethiopia. The objectives of this work were to: 1) identify the IK on use and management of WEPs by transhumants and settled farmers, 2) analyze the diversity of IK and its implication for conservation of WEPs and household food security.

\section{Study area}

The study was conducted in the semiarid zone of East Shewa in Fantalle and Boosat districts located between $7^{\circ} 12^{\prime}-9^{\circ} 14^{\prime} \mathrm{N}$ latitudes and $38^{\circ} 57^{\prime}-39^{\circ} 32^{\prime} \mathrm{E}$ longitudes in the northern part of the Great East African Rift Valley in Ethiopia (Figure 1). The climate of the area is hot with erratic, variable rainfall, resulting in unreliability for agricultural activities. Economic activities of the area are mostly livestock production but people in Boosat generally practice mixed agriculture consisting of livestock and crop production. In recent years people have tended to intensify crop (cereal) cultivation due to population pressure and shortage of pasture lands. This has aggravated land degradation especially with enhanced aridity due to climate change (FDFED 2009). The area lies in the broad leaved vegetation category of the Somalia-Maasi center of endemism described by White (1983). This consists of Acacia woodland vegetation (Demissew \& Fiiris 2009). It harbors a diversity of plants and wild animals including many WEPs. However, this level of diversity is in decline due to anthropogenic factors and climate change (FDFED 2009). This has affected both natural resources and the food and health security of the area. The study area was selected because of the expected existence of diverse indigenous knowledge among transhumant pastoralists. The neighboring settled farmers were selected for comparative analysis of IK between settled farming and transhumant lifestyles.

\section{Methods}

A reconnaissance survey was conducted between October and November 2009 to produce a specific description of the study sites. After selecting the study sites, discussions were carried out with the respective responsible 


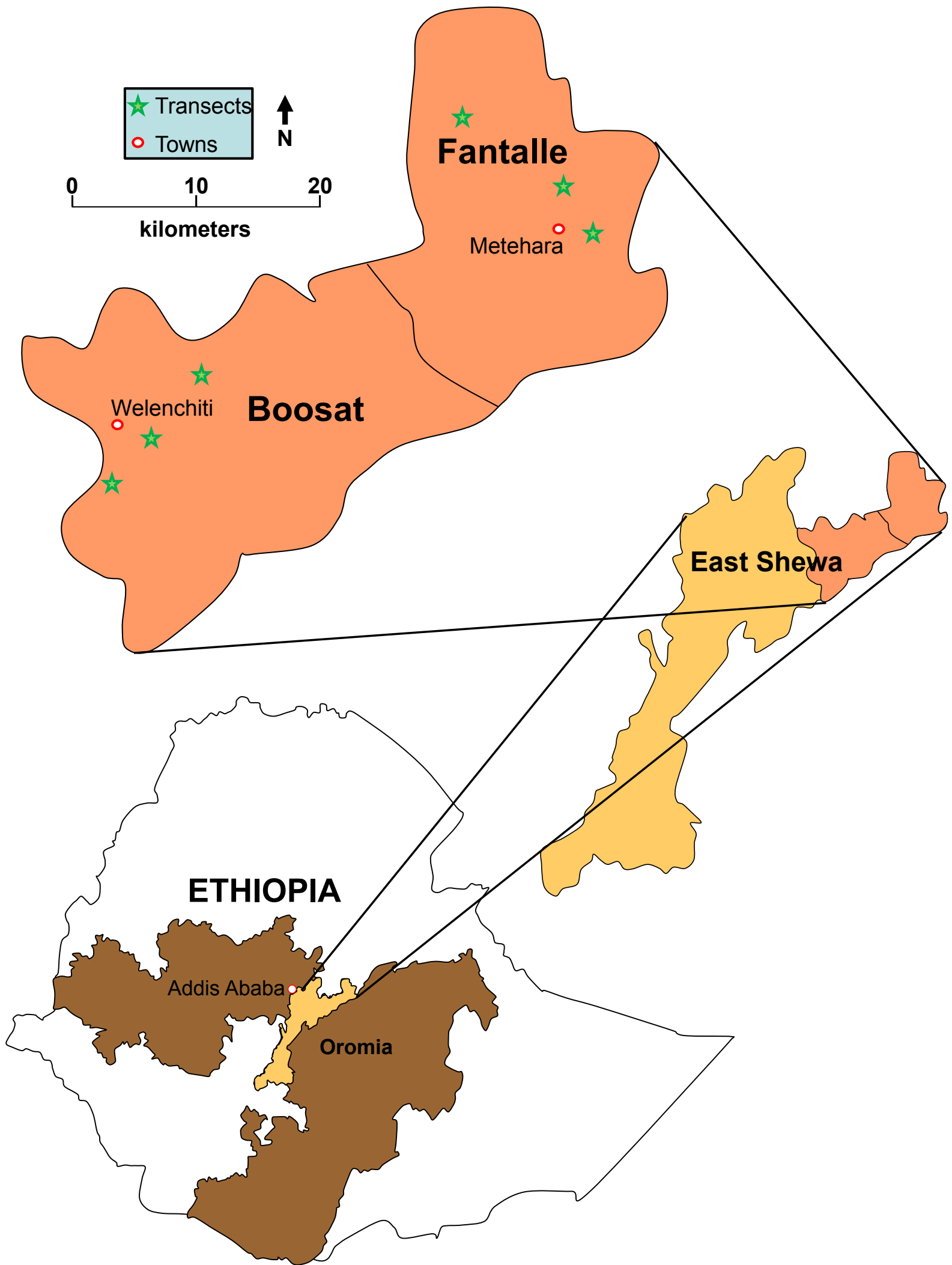

Figure 1. Study area transects in Fantalle and Boosat districts of East Shewa, Oromia National Regional State, Ethiopia. 
government officials. The discussions were conducted after clear explanation on the objectives, planned activities and duration of the research. Rural kebeles (villages) were then selected that met the selection criteria. Formal letters were written to selected rural kebeles by the responsible district offices and the researcher was introduced with kebele administrative officials and community elders by district officials. It was essential to maintain contact with the local people while studies were conducted. This procedure satisfied local customs and official ethical guidelines on carrying out ethnobotanical research. The government bodies and the local community members have fully consented and facilitated the work.

\section{Informant origin, category and year of engagement}

All informants who have lived in the area for a decade and more were considered in the selection of a sample population. This was to ensure that they have sufficient knowledge of the socioeconomics and the natural settings of the area. Informants involved in this study were transhumants and settled farmers of the Oromo people.

The study sites were selected purposively to document the IK of transhumant pastoralists and comparative analysis with neighboring settled farmers. Six zones (three from each district) of Boosat and Fantalle were selected on the basis of vegetation diversity, topography and difference in lifestyles. Knowledgeable key informants and focus group discussants were identified in each study site with the help of development workers and community leaders (Balemie \& Kebebew 2006, IIRR 1996, Martin 1995).

\section{Data collection}

A sample population was selected using the village registrar. Ethnobotanical data collection was done by interviewing 120 (60 informants from each district) who were drawn from randomly selected households. A semi-structured questionnaire, as described by Martin (1995) and Cotton (1996), was employed with transhumant and settled farmers to acquire ethnobotanical data comprising uses, management and conservation practices. WEPs and associated IK on uses and management were identified in-situ by through field interviews (Knapp \& Fernandez-Gimenez 2009) with key informants. Complementary data was collected through focus group discussions with knowledgeable people from each study site (Cotton 1996, IIRR 1996, Martin 1995). WEPs species reported by transhumant and settled farmers were separately identified in-situ. Voucher specimens were collected, identified, and deposited the National Herbarium, Biology Department, Science Faculty Addis Ababa University (ETH).

\section{Data analysis}

Identified WEPs were summarized in tables with frequencies and percentages based on their major use category in each community. Data from interviews of households comprising knowledge of uses and management practices (methods of collection, materials used for collecting, storage, preparation and uses and conservation) was analyzed using direct matrix ranking (Cotton 1996). Comparative analysis of IK on use and management of WEPs between communities in transhumant and settled farmers areas were performed with a Chi-square $\left(X^{2}\right)$ test using SPSS version 16.

Species identified by transhumant and settled farmers were recorded in an Excel spread sheet. Descriptive statistics were summarized into botanical families, habits, use categories and parts used (Cotton 1996, Martin 1995). Jaccard's Similarity Coefficient was calculated to determine species use similarities between study communities (Hoft et al. 1999) and habitats (Kent \& Coker 1992). Cultural (Ladio et al. 2006) and habitat diversity (Marsden \& Pilgrim 2003) were compared between sites.

\section{Results}

The total number of WEPs cited by Karrayu transhumants and settled farmers with their major uses was 37 and 31 by settled farmers. The plants reported include species with multipurpose uses in the study area. Transhumants have more IK on multiple uses of WEPs such as food, forage and fuel wood. Jaccard's Similarity Coefficient was $41 \%$ for WEPs, and $47 \%$ for use as forage plants (Table 1 ). Results of interviews and analysis are presented in Tables 1-15. Voucher specimens are cited in Appendix 1. The following major categories are directly or indirectly related to livelihoods in the area through income generation.

\section{Wild edible plant collecting habitats}

$36.7 \%$ of transhumants and $15.8 \%$ of settled farmers collect WEPs from forests. Settled farmers mostly collect WEPs from human managed habitats such as areas of agroforestry and home gardens (Table 2).

Table 1. Jaccard's coefficient of similarity for wild edible plant use between communities in East Shewa, Ethiopia.

\begin{tabular}{|l|c|c|c|c|c|c|}
\hline $\begin{array}{l}\text { Major use } \\
\text { Categories }\end{array}$ & $\begin{array}{c}\text { Total No. } \\
\text { of spp }\end{array}$ & $\begin{array}{c}\text { Trans- } \\
\text { humants }\end{array}$ & $\begin{array}{c}\text { Settled } \\
\text { Farmers }\end{array}$ & $\begin{array}{c}\text { Commonly } \\
\text { used spp }\end{array}$ & $\begin{array}{c}\text { Coefficient } \\
\text { Percentage } \\
\text { Similarity }\end{array}$ \\
\hline Forage/fodder & 40 & 37 & 31 & 28 & 0.41 & 41.18 \\
\hline Fuel wood & 35 & 34 & 30 & 30 & 0.47 & 46.88 \\
\hline
\end{tabular}




\section{Feyssa et al. - Comparative Analysis of Indigenous Knowledge on Use and Management of Wild Edible Plants: The case of Central East Shewa, Ethiopia}

Table 2. District preferences for habitats to collect wild edible plants in two districts of East Shewa, Ethiopia.

\begin{tabular}{|c|c|c|c|c|c|c|c|c|}
\hline \multirow{2}{*}{$\begin{array}{l}\text { Respondent } \\
\text { District }\end{array}$} & \multicolumn{7}{|c|}{ Wild Edible Plant Habitats } & \multirow[b]{2}{*}{ Tota } \\
\hline & $\begin{array}{c}\text { Gardens } \\
\text { (G) }\end{array}$ & $\begin{array}{c}\text { Forests } \\
\text { (F) }\end{array}$ & $\begin{array}{l}\text { Bush } \\
\text { Lands }\end{array}$ & $\begin{array}{l}\text { Agro- } \\
\text { forestry }\end{array}$ & $\begin{array}{l}\text { Living } \\
\text { Fences }\end{array}$ & $\begin{array}{c}\text { Roadsides } \\
\text { (R) }\end{array}$ & G, F \& R & \\
\hline \multicolumn{9}{|l|}{ Boosat } \\
\hline Frequency & 5 & 19 & 5 & 15 & 8 & 3 & 5 & 60 \\
\hline$\%$ of Total & 4.2 & 15.8 & 4.2 & 12.5 & 6.7 & 2.5 & 4.2 & 50 \\
\hline \multicolumn{9}{|l|}{ Fantalle } \\
\hline Frequency & 3 & 44 & 3 & 3 & 3 & 4 & 0 & 60 \\
\hline$\%$ of Total & 2.5 & 36.7 & 2.5 & 2.5 & 2.5 & 3.3 & 0.0 & 50 \\
\hline \multicolumn{9}{|l|}{ Total } \\
\hline Frequency & 8 & 63 & 8 & 18 & 11 & 7 & 5 & 120 \\
\hline$\%$ of Total & 6.7 & 52.5 & 6.7 & 15.0 & 9.2 & 5.8 & 4.2 & 100 \\
\hline
\end{tabular}

\section{Gender and habitats of collecting wild edible plants}

Females collect WEPs from similar habitats as males. Forest was the relatively preferred habitat for collecting WEPs. These results indicated that females have considerable knowledge of biodiversity of multipurpose WEPs. The habitats known by females and males do not significantly vary $\left(X^{2}=6.716, P=0.348\right)$ but there is significant variation between districts $X^{2}=4.1, P=0.042$ (Table 3).

\section{Analysis of strategies of preventing threats to wild edible plants}

In spite of population pressure, people of the study area have knowledge useful for preventing threats to multipurpose WEPs. When informants were asked, "Are there ways of preventing threats to WEPs", $17.5 \%$ of settled farmers and $30.8 \%$ of transhumants asserted that there are ways of preventing treats to WEPs. When knowledge of transhumant and settled farmers were compared on preventing threats to WEPs, two of the parameters showed significant differences and two were not significantly different (Table 4).
However, informants expressed concern over the scarcity of seeds, crop and pastoral lands, and areas for WEPs to flourish. This indicates conflicting interests about various uses and interdiffusion of IK on use and management of WEPs between transhumants and settled farmers.

Local people indicated that they need to get support about how to better use WEPs and conserve them. They also indicated the need of valuing their IK on use and management of resources (Table 4). Strategies for preventing loss of WEPs were not significantly different between populations. Strategies of creating awareness and enhancing participatory planning of implementation of projects to prevent threats however, did vary significantly. This result asserts the existence of differences in IK for prevention of threats to WEPs (Table 4). In this case transhumants were more knowledgeable than settled farmers in strategies of preventing threats to WEPs. The results also showed that the local people of the two districts need their IK on use and management of WEPs recognized and supported by policy and extension services. This calls for participatory resource management

Table 3. Gender preferences for habitats to collect wild edible plants in two districts of East Shewa, Ethiopia.

\begin{tabular}{|c|c|c|c|c|c|c|c|c|}
\hline \multirow{2}{*}{$\begin{array}{l}\text { Respon- } \\
\text { dents }\end{array}$} & \multicolumn{7}{|c|}{ Wild Edible Plant Habitats } & \multirow[b]{2}{*}{ Total } \\
\hline & $\begin{array}{c}\text { Gardens } \\
\text { (G) }\end{array}$ & $\begin{array}{l}\text { Forests } \\
\text { (F) }\end{array}$ & $\begin{array}{l}\text { Bush } \\
\text { Lands }\end{array}$ & $\begin{array}{c}\text { Agro- } \\
\text { forestry }\end{array}$ & $\begin{array}{c}\text { Living } \\
\text { Fences }\end{array}$ & $\begin{array}{c}\text { Roadsides } \\
\text { (R) }\end{array}$ & G, F \& R & \\
\hline \multicolumn{9}{|l|}{ Male } \\
\hline Frequency & 6 & 48 & 5 & 12 & 5 & 5 & 2 & 83 \\
\hline$\%$ of Total & 5.0 & 40.0 & 4.2 & 10.0 & 4.2 & 4.2 & 1.7 & 69.2 \\
\hline \multicolumn{9}{|l|}{ Female } \\
\hline Frequency & 2 & 15 & 3 & 6 & 6 & 2 & 3 & 37 \\
\hline$\%$ of Total & 1.7 & 12.5 & 2.5 & 5.0 & 5.0 & 1.7 & 2.5 & 30.8 \\
\hline \multicolumn{9}{|l|}{ Total } \\
\hline Frequency & 8 & 63 & 8 & 18 & 11 & 7 & 5 & 120 \\
\hline$\%$ of Total & 6.7 & 52.5 & 6.7 & 15.0 & 9.2 & 5.8 & 4.2 & 100 \\
\hline
\end{tabular}


Table 4. Generalized strategies for preventing threats to wild edible plants in two districts of East Shewa, Ethiopia. *Significant at $p=0.05$.

\begin{tabular}{|c|c|c|c|c|c|c|c|}
\hline \multicolumn{2}{|l|}{ Methods } & \multicolumn{2}{|c|}{ No. of respondents } & \multirow{3}{*}{$\begin{array}{c}\text { Total } \\
58 \\
\end{array}$} & \multicolumn{3}{|c|}{ Summary statistics } \\
\hline & & \multirow{2}{*}{$\begin{array}{c}\text { Boosat } \\
21\end{array}$} & \multirow{2}{*}{\begin{tabular}{|c|} 
Fantalle \\
37
\end{tabular}} & & \multirow[t]{2}{*}{ Mean $\pm S E M$} & \multirow[t]{2}{*}{$x^{2}$} & \multirow[t]{2}{*}{$P, d f=1$} \\
\hline Create awareness of WEPs & Frequency & & & & & & \\
\hline use by indigenous people & $\%$ of Total & 17.5 & 30.8 & 48.3 & $0.48 \pm 0.047$ & 8.54 & $0.01^{*}$ \\
\hline \multirow[t]{2}{*}{ Value indigenous knowledge } & Frequency & 5 & 8 & 13 & & & \\
\hline & $\%$ of Total & 4.2 & 6.7 & 10.8 & $0.11 \pm 0.028$ & 0.78 & 0.56 \\
\hline \multirow{2}{*}{$\begin{array}{l}\text { Enhance participatory planning } \\
\& \text { implementation of projects }\end{array}$} & Frequency & 30 & 8 & 38 & & & \\
\hline & $\%$ of Total & 25.0 & 6.7 & 31.7 & $0.32 \pm 0.043$ & 18.6 & $0.00^{*}$ \\
\hline \multirow{2}{*}{$\begin{array}{l}\text { Alternative livelihoods for local } \\
\text { people }\end{array}$} & Frequency & 4 & 7 & 11 & & & \\
\hline & $\%$ of Total & 3.3 & 5.8 & 9.2 & $0.09 \pm 0.026$ & 0.10 & 1.00 \\
\hline Total & $\%$ Total & $60(50 \%)$ & $60(50 \%)$ & $120(100 \%)$ & & & \\
\hline
\end{tabular}

to sustain WEPs and maintain their contribution to food and health care of semiarid people among other functions.

\section{Strategies of conservation for specific species of wild edible plants}

The present study identified indigenous conservation strategies such as growing WEPs in grasslands, using agroforestry, and combinations of growing WEPs as living fences and in agroforestry (Table 5). The strategies were species specific which can be used as solid ground for future policy and development actions. These imply in-situ conservation combined with additional ex-situ strategies. A list of documented WEPs is given in Appendix 1.

Table 5. Habitats used for conserving preferred wild edible plants by local people in two districts of East Shewa, Ethiopia. Species growing in multiple habitats: $5+6=$ Agroforestry \& grasslands, $3+4=$ Home gardens \& live fences; $2+3=$ Hedges \& homegardens; $4+5=$ Living fences and agroforestry; 1-6= Combination of all strategies; $1-4=$ all except agroforestry \& grassland; All species of Grewia are provided in Appendix 1.

\begin{tabular}{|c|c|c|c|c|c|c|c|c|c|c|c|}
\hline \multirow[t]{2}{*}{ Preferred WEP } & \multirow{2}{*}{$\begin{array}{c}\text { Protect } \\
\text { Vegetation }\end{array}$} & \multicolumn{10}{|c|}{ Habitats } \\
\hline & & $\begin{array}{l}\text { Living } \\
\text { Fence }\end{array}$ & $\begin{array}{l}\text { Agro- } \\
\text { forestry }\end{array}$ & $\begin{array}{l}\text { Grass- } \\
\text { lands }\end{array}$ & $5+6$ & $3+4$ & $2+3$ & $4+5$ & $1-6$ & $1-4$ & Total \\
\hline $\begin{array}{l}\text { Ziziphus spina-christi } \\
\text { (L.) Desf. }\end{array}$ & 1 & 3 & 12 & 38 & 1 & 4 & 1 & 5 & 5 & 11 & 97 \\
\hline $\begin{array}{l}\text { Balanites aegyptiacus } \\
\text { (L.) Delile }\end{array}$ & 1 & 1 & 3 & 26 & 1 & 9 & 0 & 2 & 3 & 6 & 52 \\
\hline $\begin{array}{l}\text { Berchemia discolor } \\
\text { (Klotzsch) Hemsl. }\end{array}$ & 4 & 0 & 6 & 14 & 0 & 4 & 0 & 1 & 0 & 1 & 30 \\
\hline Ximenia americana L. & 1 & 0 & 2 & 11 & 0 & 3 & 0 & 0 & 3 & 6 & 26 \\
\hline $\begin{array}{l}\text { Grewia flavescens } \\
\text { Juss. }\end{array}$ & 0 & 1 & 2 & 7 & 0 & 3 & 0 & 1 & 0 & 3 & 17 \\
\hline Grewia villosa Willd. & 1 & 0 & 6 & 1 & 0 & 5 & 1 & 1 & 0 & 1 & 16 \\
\hline Grewia spp. & 0 & 0 & 2 & 0 & 0 & 3 & 0 & 1 & 3 & 7 & 16 \\
\hline Carissa spinarum L. & 0 & 0 & 0 & 0 & 0 & 2 & 0 & 0 & 3 & 6 & 11 \\
\hline $\begin{array}{l}\text { Dobera glabra (Forssk.) } \\
\text { Poir. }\end{array}$ & 2 & 0 & 0 & 6 & 1 & 0 & 0 & 0 & 0 & 0 & 9 \\
\hline Tamarindus indica L. & 1 & 0 & 1 & 6 & 0 & 0 & 0 & 0 & 0 & 0 & 8 \\
\hline $\begin{array}{l}\text { Premna resinosa } \\
\text { (Hochst.) Schauer }\end{array}$ & 0 & 0 & 0 & 6 & 1 & 0 & 0 & 0 & 0 & 0 & 7 \\
\hline $\begin{array}{l}\text { Acacia senegal (L.) } \\
\text { Willd. }\end{array}$ & 0 & 0 & 2 & 0 & 0 & 1 & 0 & 0 & 0 & 0 & 3 \\
\hline
\end{tabular}




\section{Feyssa et al. - Comparative Analysis of Indigenous Knowledge on Use and Management of Wild Edible Plants: The case of Central East Shewa, Ethiopia}

Table 6. Management of wild edible plants by local people in two districts of East Shewa, Ethiopia. Bo= Boosat, Fa= Fantalle, $X=$ management practices implemented, $X^{*}=$ Intensified practice, $X^{* *}=$ Historical use, the plant is now locally rare.

\begin{tabular}{|c|c|c|c|c|c|c|c|c|c|c|}
\hline \multirow[t]{2}{*}{ WEP } & \multicolumn{2}{|c|}{$\begin{array}{c}\text { Mass } \\
\text { cultivation }\end{array}$} & \multicolumn{2}{|c|}{ Agroforestry } & \multicolumn{2}{|c|}{ Pastures } & \multicolumn{2}{|c|}{$\begin{array}{l}\text { Living } \\
\text { Fences }\end{array}$} & \multicolumn{2}{|c|}{$\begin{array}{l}\text { Home } \\
\text { gardens }\end{array}$} \\
\hline & Bo & $\mathbf{F a}$ & Bo & $\mathrm{Fa}$ & Bo & $\mathbf{F a}$ & Bo & $\mathbf{F a}$ & Bo & $\mathbf{F a}$ \\
\hline Ziziphus spina-christi (L.) Desf. & - & - & $X^{*}$ & $x$ & $\mathrm{X}$ & $X^{*}$ & $X^{*}$ & $x$ & $x$ & $\mathrm{X}$ \\
\hline Balanites aegyptiacus (L.) Delile & - & - & $x$ & $x$ & $\mathrm{X}$ & $X^{*}$ & $X^{*}$ & $x$ & $x$ & $x$ \\
\hline Grewia flavescens Juss. & - & - & - & & $\mathrm{X}$ & $X^{*}$ & $X^{*}$ & $x$ & $x$ & $\mathrm{X}$ \\
\hline Ximenia americana L. & - & - & - & & $X^{* *}$ & $X^{* *}$ & $X^{* *}$ & $X^{* *}$ & $X^{* *}$ & $X^{* *}$ \\
\hline $\begin{array}{l}\text { Berchemia discolor (Klotzsch) } \\
\text { Hemsl. }\end{array}$ & - & - & - & & $X$ & $X^{*}$ & $X^{*}$ & $\mathrm{X}$ & $\mathrm{X}$ & $X$ \\
\hline Acacia senegal (L.) Willd. & - & - & - & & $\mathrm{X}$ & $X^{*}$ & $X^{*}$ & $x$ & $\mathrm{X}$ & $\mathrm{X}$ \\
\hline Grewia makranica Rech.f. \& Esfand. & - & - & - & - & - & - & - & - & - & $\mathrm{X}$ \\
\hline
\end{tabular}

\section{Practical field observation results on management of wild edible plants}

Observations were made with key informants during field interviews to identify the practical management of WEPs. $7(19 \%)$ of the WEPs were managed in pasture land, in living fences, and through traditional agroforestry. Managing WEPs in pasture land by transhumants, and live fencing and agroforestry by settled farmers were relatively intensified management strategies. None of the WEPs involved mass cultivation (Table 6). We interpret this to mean that the existing potential is not yet recognized. This gap in sustainable utilization calls for better management and utilization of WEPs.

\section{Conservation strategies vs gender}

Analysis of interview data revealed that females take active parts in conservation activities. Although personal interviews with females were not so easy due to cultural rules that restrict their availability for interviews, data obtained from 37 women revealed their involvement in conservation. Their engagement in conservation of multipurpose WEPs showed a fair and reasonable share of females as a community. Their share of participation in various WEP management efforts is similar to that of men (Table 7). This indicates actual involvement of females in conservation and management of WEPs in semiarid Ethiopia.

\section{Transfer of knowledge on wild edible plant use and management through generations}

Fortynine (49\%) of interview responses showed that among transhumants transfer of knowledge across generations has been the responsibility of the community as a whole. However, among settled farmers it has been the responsibility of fathers' and mothers' 28 (23.3\%) with the wider community also being a key source of knowledge (Table 8). This was asserted by focus group discussions. The ways transhumants and settled farmers acquire IK is different, revealing the heterogeneity of ways to acquire knowledge for sustainable use of WEPs (Table 8). This IK can be further harnessed to enhance development in semiarid areas. Knowledge of communities of different life styles needs to be complemented to get the whole package of IK.

Table 7. Differences in gender responses by local people about generalized conservation measures practiced to sustain wild edible plants (WEPs) in two districts of East Shewa, Ethiopia.

\begin{tabular}{|c|c|c|c|c|c|c|c|c|c|}
\hline \multirow{2}{*}{\multicolumn{2}{|c|}{ Respondents }} & \multicolumn{7}{|c|}{$\begin{array}{l}\text { Conservation Measures Practiced to Sustain WEPs? } \\
\qquad \mathrm{X}^{2}=8.633, \mathrm{df}=6, \mathrm{P}=0.195\end{array}$} & \multirow[b]{2}{*}{ Total } \\
\hline & & $\begin{array}{l}\text { Agro- } \\
\text { forestry }\end{array}$ & $\begin{array}{l}\text { Home } \\
\text { garden }\end{array}$ & $\begin{array}{l}\text { Living } \\
\text { Fences }\end{array}$ & $\begin{array}{l}\text { Farm } \\
\text { boarder }\end{array}$ & $\begin{array}{c}\text { Individual } \\
\text { protected } \\
\text { area }\end{array}$ & $\begin{array}{l}\text { Protect } \\
\text { vegetation }\end{array}$ & $\begin{array}{l}\text { Decrease } \\
\text { deforestation }\end{array}$ & \\
\hline \multirow[t]{2}{*}{ Male } & Count & 12 & 8 & 7 & 5 & 15 & 13 & 23 & 83 \\
\hline & $\%$ of Total & 10.0 & 6.7 & 5.8 & 4.2 & 12.5 & 10.8 & 19.2 & 69.2 \\
\hline \multirow[t]{3}{*}{ Female } & Count & 6 & 7 & 5 & 3 & 3 & 9 & 4 & 37 \\
\hline & $\%$ of Total & 5.0 & 5.8 & 4.2 & 2.5 & 2.5 & 7.5 & 3.3 & 30.8 \\
\hline & Count & 18 & 15 & 12 & 8 & 18 & 22 & 27 & 120 \\
\hline Total & $\%$ of Total & 15.0 & 12.5 & 10.0 & 6.7 & 15.0 & 18.3 & 22.5 & 100 \\
\hline
\end{tabular}


Table 8. Sources of knowledge on use and management of wild edible plants (WEPs) in two districts of East Shewa, Ethiopia. *Significant at $p=0.05$.

\begin{tabular}{|c|c|c|c|c|c|}
\hline \multirow{2}{*}{\multicolumn{2}{|c|}{ Respondents }} & \multicolumn{4}{|c|}{ Knowledge sources on use \& management of WEPs } \\
\hline & & Transhumants & Settled farmers & Mother \& father & Total \\
\hline \multirow[t]{3}{*}{ Boosat } & Count & 10 & 25 & 25 & 60 \\
\hline & $\%$ within district & 16.9 & 89.3 & 75.8 & 50 \\
\hline & $\%$ of Total & 8.3 & 20.8 & 20.8 & 50 \\
\hline \multirow[t]{3}{*}{ Fantalle } & Count & 49 & 3 & 8 & 60 \\
\hline & $\%$ within district & 83.1 & 10.7 & 24.2 & 50 \\
\hline & $\%$ of Total & 40.8 & 2.5 & 6.7 & 50 \\
\hline \multirow[t]{5}{*}{ Total } & Count & 59 & 28 & 33 & 120 \\
\hline & $\%$ of Total & 49.2 & 23.3 & 27.5 & 100 \\
\hline & Mean & $0.49 \pm 0.46$ & $0.27 \pm 0.46$ & $0.02 \pm 0.37$ & \\
\hline & $x^{2}$ & 0.000 & 0.000 & 0.000 & \\
\hline & $P, d f=1$ & $0.000^{*}$ & $0.000^{*}$ & $0.000^{*}$ & \\
\hline
\end{tabular}

Main types of dryland agroforestry practices in East Shewa

Four broad types of management practices were observed in the study areas. 1) Agrosilviculture: This practice combines trees and annual crops. These include wild or semi-wild species such as those used in living fences and windbreaks, medicinal and aromatic plants and those used in shifting agriculture. While this practice was not distinctly observed in the study area, traditional agroforestry practices of settled farmers included saving multipurpose trees such as Ziziphus spina-christi (L.) Desf., Balanites aegyptiacus (L.) Delile, and Acacia senegal (L.) Willd. The trees were used as shade for humans, livestock and annual crops. After harvest, these trees still provide partial shade, promote soil moisture resilience, impact mulching, and provide microhabitats within a farm. The branches cut from agroforestry trees were used for fencing, construction of houses and bauma (where cattle stay at night). The leaves were used as fodder and medicine for livestock and some trees were used as food and medicine for humans. 2) Silvipastoralism: This practice has trees and livestock on wooded pasture or rangeland. These include wild or semi-wild species used in pastures, for browsing and fodder, and regenerating forests. This old practice, known as kalo by transhumants of Fantalle, has been under heavy human population pressure exacerbated by climate change and poverty. 3) Agrosilvipastoralism: This practice combines trees, crops, and livestock. These include wild or semi-wild tree and shrub species that are used in pastures and rangelands for browsing and fodder, or as multipurpose aromatic and medicinal plants. This is minimally practiced in the study area. 4) Home gardening: This practice combines various multipurpose trees, shrubs, and perennial or annual herbs. This practice is emerging among transhumants as a coping and adaptation strategy to climate change. Settled farmers were also observed applying this practice, but only with rudimen- tary intensity. This is however being intensified by some households because of shortages of forage/ fodder and multipurpose shrubs and trees.

Similarly, in many parts of Africa "farm trees" are found scattered through areas of cultivated land within and near farm fields. These trees are managed, protected and harvested by farmers to provide fuel wood, fodder, poles for construction, and edible fruits and nuts. In the Sahel, with its sandy soils of low fertility, scattered Faidherbia albida (Delile) A. Chev. trees in millet or sorghum fields increase crop yields up to two and a half times over those obtained in open fields (FAO 1999). In fact, humans have been using forests intensively for many thousands of years and their management of forest resources has resulted in the domestication of the landscape, a concept introduced to describe the case of Australian Aborigines. The term domiculture was introduced to describe this kind of domestication as opposed to the conventional genetic modification of plants through selection and breeding (FAO 1999). Wild plants may be domesticated from forests or other ecosystems to similar local habitats or near human habitations as well as into fields so that they are readily available and easily collected. This minimal form of domestication seems quite common e.g., as practiced by the Kayapo Indians of South America (Posey 1985). It is an evidence for co-domestication of forests and multiuse tree species that has resulted from interactions between local communities and forests. If it is also considered that most of the terrestrial world is in one sense or another an agroecosystem, it is difficult to maintain a strict separation between wild and cultivated plants (FAO 1999).

\section{Analysis of dynamics of wild edible plant use and management practices in the study area}

Informants were asked "Is there change in use \& management of WEPs?". All (100\%) informants confirmed that 


\section{Feyssa et al. - Comparative Analysis of Indigenous Knowledge on Use and Management of Wild Edible Plants: The case of Central East Shewa, Ethiopia}

Table 9. Reasons for change in use and management of wild edible plants (WEPs) in two districts of East Shewa, Ethiopia. IK=Indigenous knowledge. *Significant at $p=0.05$.

\begin{tabular}{|c|c|c|c|c|c|c|c|}
\hline \multicolumn{2}{|c|}{ Respondents } & \multirow{2}{*}{\multicolumn{6}{|c|}{ Reasons for change in use \& management of WEPs }} \\
\hline & & \multirow{2}{*}{$\begin{array}{c}\text { Enhanced } \\
\text { tree pasture }\end{array}$} & \multirow{2}{*}{$\begin{array}{c}\begin{array}{c}\text { Expansion of } \\
\text { agriculture }\end{array} \\
13\end{array}$} & & & & \\
\hline Boosat & Frequency & & & $\begin{array}{c}\text { Increase of } \\
\text { human } \\
\text { population }\end{array}$ & $\begin{array}{c}\text { Erosion of IK } \\
\text { \& weakening } \\
\text { traditional } \\
\text { institutions }\end{array}$ & $\begin{array}{c}\begin{array}{c}\text { Livestock } \\
\text { density \& } \\
\text { population }\end{array} \\
4\end{array}$ & \begin{tabular}{|c|} 
Total \\
60 \\
\end{tabular} \\
\hline & $\%$ of Total & 2.5 & 10.8 & 17.5 & 15.8 & 3.3 & 50 \\
\hline \multirow[t]{2}{*}{ Fantalle } & Frequency & 13 & 8 & 6 & 21 & 12 & 60 \\
\hline & $\%$ of Total & 10.8 & 6.7 & 5.0 & 17.5 & 10.0 & 50 \\
\hline \multirow[t]{5}{*}{ Total } & Frequency & 16 & 21 & 27 & 40 & 16 & 120 \\
\hline & $\%$ of Total & 13.3 & 17.5 & 22.5 & 33.3 & 13.3 & 100 \\
\hline & Mean & $0.13 \pm 0.031$ & $0.18 \pm 0.035$ & $0.23 \pm .039$ & $0.33 \pm .043$ & $0.13 \pm .031$ & \\
\hline & $x^{2}$ & 7.212 & 1.443 & 11.925 & 0.150 & 4.615 & \\
\hline & $P, d f=1$ & $0.014^{*}$ & 0.337 & $0.001^{*}$ & 0.847 & 0.058 & \\
\hline
\end{tabular}

there is a change in use and management of WEPs. Erosion of IK and weakening of traditional institutions were major reasons $(33.3 \%)$ provided for changes in WEP management (Table 9). Some changes were taken as copping opportunities that individuals have applied such as enhancing tree pasture conservation (13.3\%). This practice and effects of human population changes vary between transhumants and settled farmers $(P<0.05)$. In the transhumant areas human population changes were considered less important than in settled farmers' areas.

\section{Exemplary management practices of wild edible plants in East Shewa}

Some transhumants have conserved Z. spina-christi and $B$. aegyptiacus in their pasture lands and around their settlements. This was because their food, forage contributions and income generation were recognized by local communities. Some of them have shown their future plan to plant more trees, especially $Z$. spina-christi, for its edible fruit, and forage for camels and goats, based on their experiences. Discussion with key informants revealed that use conflict has been emerging from multipurpose uses of Z. spina-christi, B. aegyptiacus and other most preferred WEPs. For instance, use conflict occurs between people using WEPs for food and livestock fodder and commercial purposes such as fuel wood (charcoal and fire wood) and construction.

Ex-situ conservation practices in both areas were not widely practiced. This is probably due to harsh environments, the transhumant character of pastoralists, and more emphasis placed on livestock development than the use of vegetation products as food. People were also more knowledgeable about medicinal uses of these plants than their food value. The implication is that transhumants depend on traditional medication more than modern medi- cine probably due to its affordability and availability in local home vegetation. They were more concerned for the conservation and potential loss of these plants from the forest and this is consistent with their protection practices. Relatively more emphasis was placed on medicinal plants than WEPs by transhumant areas. Settled framers have a different experience showing more interest in improved crop varieties and modern medicine.

\section{Management strategies of natural resources and wild edible plants by people of the study area}

$120(100 \%)$ informants responded that local people have rich knowledge of managing natural resources in general and WEPs in particular. Some of the traditional management practices that informants recommended (and researchers also found acceptable) are presented in Figure 10. Specific practices depend on the lifestyles of people in the two districts. For transhumants, grasslands are the basic niche and agroforestry, home gardens and living fences are more relevant for settled farmers. This observation should be a foundation for future management strategies to promote WEPs utilization.

Except the individually protected areas and live fencing methods, other practices by transhumant pastoralists and settled farmers showed significant variation at $(\mathrm{P}<0.005)$ (Table 10). This could be grounds for planning of conservation of WEPs in semiarid areas. The results indicate that transhumants are more concerned in protecting the vegetation by decreasing deforestation with WEPs than farmers. 
Table 10. Conservation measures practiced by communities to sustain wild edible plants (WEPs) in two districts of East Shewa, Ethiopia. ${ }^{*}$ Significant at $\mathrm{p}=0.05$.

\begin{tabular}{|c|c|c|c|c|c|c|c|c|c|}
\hline \multicolumn{2}{|c|}{ Respondents } & \multicolumn{8}{|c|}{ Conservation measures practiced to sustain WEPs } \\
\hline & & \multirow{2}{*}{ 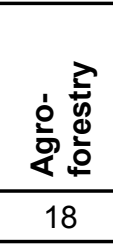 } & \multirow{2}{*}{ 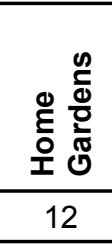 } & \multirow{2}{*}{ 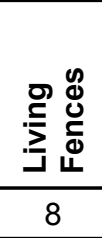 } & \multirow{2}{*}{ 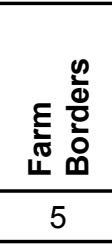 } & \multirow{2}{*}{ 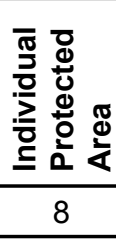 } & \multirow{2}{*}{ 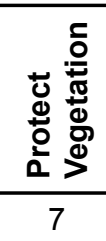 } & \multirow{2}{*}{ 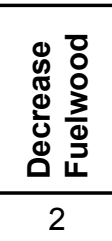 } & \multirow{2}{*}{$\begin{array}{c}\text { Total } \\
\\
60\end{array}$} \\
\hline Boosat & Frequency & & & & & & & & \\
\hline & $\%$ of Total & 15 & 10.0 & 6.7 & 4.2 & 6.7 & 5.8 & 1.7 & 50 \\
\hline \multirow[t]{2}{*}{ Fantalle } & Frequency & 0 & 3 & 4 & 3 & 10 & 15 & 25 & 60 \\
\hline & $\%$ of Total & 0.0 & 2.5 & 3.3 & 2.5 & 8.3 & 12.5 & 20.8 & 50 \\
\hline \multirow[t]{5}{*}{ Total } & Frequency & 20 & 15 & 12 & 4 & 18 & 24 & 27 & 120 \\
\hline & $\%$ of Total & 15 & 12.5 & 10.0 & 3.3 & 15.0 & 20.0 & 22.5 & 100 \\
\hline & Mean & $\begin{array}{c}0.15 \\
\pm 0.03\end{array}$ & $\begin{array}{c}0.10 \\
\pm 0.03\end{array}$ & $\begin{array}{c}0.09 \\
\pm 0.03\end{array}$ & $\begin{array}{c}0.13 \\
\pm 0.03\end{array}$ & $\begin{array}{c}0.13 \\
\pm 0.34 \\
\end{array}$ & $\begin{array}{c}0.30 \\
\pm 0.04\end{array}$ & $\begin{array}{c}0.25 \\
\pm 0.40\end{array}$ & \\
\hline & $x^{2}$ & 21.18 & 13.33 & 0.90 & 21.66 & 1.15 & 19.21 & 30.04 & \\
\hline & $P, d f=1$ & $0.000^{*}$ & $0.000^{*}$ & 0.529 & $0.001^{*}$ & 0.421 & $0.000^{*}$ & $0.000^{*}$ & \\
\hline
\end{tabular}

Traditional manipulation practices to collect wild edible plants

Traditional manipulations practiced to collect WEPs showed variation between transhumants and settled farmers but such variation was not significantly different between communities $(P>0.05)$. The results indicate interchange of traditional knowledge on use and management of WEPs between the two life styles (Table 11). This specific result supported the research hypothesis that "Trans- humant and settled farmers have similar IK practices for use and management of WEPs."

\section{Status of wild edible plant use}

All $(100 \%)$ of the informants expressed that they apply their IK to the use and management of WEPs and other natural resources. The informants indicated that local people have traditional knowledge of WEPs and unanimously expressed their strong feeling that, IK is still rich in the community. However, $90.83 \%$ of informants respond-

Table 11. Traditional manipulations practiced to collect wild edible plants (WEPs) in two districts of East Shewa, Ethiopia. Not significant at $\mathrm{p}=0.05$.

\begin{tabular}{|c|c|c|c|c|c|c|c|}
\hline \multirow{2}{*}{\multicolumn{2}{|c|}{ Manipulations }} & \multicolumn{6}{|c|}{ Responses by districts } \\
\hline & & \multirow{2}{*}{$\frac{\text { Boosat }}{3}$} & \multirow{2}{*}{$\begin{array}{c}\text { Fantalle } \\
10\end{array}$} & \multirow{2}{*}{$\begin{array}{c}\% \text { of Total } \\
13\end{array}$} & \multirow[t]{3}{*}{ Mean } & \multirow[t]{3}{*}{$x^{2}$} & \multirow[t]{3}{*}{$P, d f=1$} \\
\hline Leaf & Frequency & & & & & & \\
\hline cuttings & $\%$ within District & 5.0 & 16.7 & 10.8 & & & \\
\hline & $\%$ of Total & 2.5 & 8.3 & 10.8 & $0.09 \pm 0.03$ & 4.277 & 0.075 \\
\hline \multirow{3}{*}{$\begin{array}{l}\text { Fruit \& } \\
\text { seeds }\end{array}$} & Frequency & 43 & 46 & 89 & & & \\
\hline & $\%$ within District & 71.7 & 76.7 & 74.2 & & & \\
\hline & $\%$ of Total & 35.8 & 38.3 & 74.2 & $0.74 \pm 0.05$ & 0.391 & 0.677 \\
\hline \multirow{3}{*}{$\begin{array}{l}\text { Stem } \\
\text { cuttings }\end{array}$} & Frequency & 6 & 2 & 8 & & & \\
\hline & $\%$ within District & 10.0 & 3.3 & 6.7 & & & \\
\hline & $\%$ of Total & 5.0 & 1.7 & 6.7 & $0.07 \pm 0.23$ & 2.143 & 0.272 \\
\hline \multirow{3}{*}{$\begin{array}{l}\text { Leaves, } \\
\text { fruit, seeds } \\
\text { \& stem } \\
\text { together }\end{array}$} & Frequency & 8 & 2 & 10 & & & \\
\hline & $\%$ within District & 13.3 & 3.3 & 8.3 & & & \\
\hline & $\%$ of Total & 6.7 & 1.7 & 8.3 & $0.08 \pm 0.03$ & 3.927 & 0.095 \\
\hline \multirow[t]{2}{*}{ Total } & Frequency & 60 & 60 & 120 & & & \\
\hline & $\%$ of Total & 50.0 & 50.0 & 100.0 & & & \\
\hline
\end{tabular}




\section{Feyssa et al. - Comparative Analysis of Indigenous Knowledge on Use and Management of Wild Edible Plants: The case of Central East Shewa, Ethiopia}

ed that traditional use and management practices are not more efficient than modern practices in light of accelerated food insecurity and livelihood problems. The implication is that communities need complementary knowledge and practices for efficient use of WEPs and natural resources to improve their livelihoods. From settled farmers $11(9.17 \%)$ indicated their belief that traditional use and management practices were more efficient than modern practices (Table 12). This differing level of IK reveals that some local people perceive that they are self sufficient using and managing natural resources in general and WEPs in particular. This implies that IK can be used for future WEPs production and assessment of sustainable utilization.

\section{Storage/storability and post harvest handling of wild edible plants}

Most of the WEPs found in the study area were collected and eaten fresh without requiring storage facilities. But, B. aegyptiacus, Ximenia americana L., Berchemia discolor (Klotzsch) Hemsl. and Z. spina-christi are stored for a maximum of 3 to 7 days under no special facility. Sand and ventilated containers such as pots are used without exposure to direct heat to prevent desiccation of fruit pulp. People observed using WEPs immediately by saving other food items since WEPs are perishable. Storage facilities are not available that are suitable in high temperatures that reach at times $35^{\circ} \mathrm{C}$ with mean maximum of $33^{\circ} \mathrm{C}$. This is another challenge in utilization of WEPs for extended periods. This should be solved by developing local affordable technologies. Longer term fruit storage could alleviate food shortages and supplement daily diets.

\section{People's perception and status of wild edible plants gathering and consumption}

Focus group discussions and participatory observations revealed that perceptions of people on edibility of WEPs varied with diversity in lifestyles. People focused on different plants and their attributes. Z. spina-christi, X. americana, B. aegyptiacus, Grewia villosa Willd., B. discolor are edible and used for multiple purposes by all age categories at all times. Although Grewia spp. are eaten by all people, some hold local beliefs that if children consume these plants, it causes lagda (malaria in Oromo lan- guage). Such beliefs are held both by transhumants and settled farmers.

\section{Ownership and status of wild edible plants}

Interviewees were asked to indicate ownership status of at least five commonly used WEPs by people of the two districts. The results indicate that most of the WEPs are communally owned and found in natural vegetation (not domesticated). Z. spina-christi has increasingly become owned by transhumant and farming communities in kalo near homesteads and farm borders (Table 13). Land use and resource tenure issues were also of concern to people. Hence, utilization in terms of its food security contribution is diminishing. The tragedy of the commons (Hardin 1968) needs to be urgently avoided through in-situ and ex-situ conservation of WEPs through domestication. In Table 13 the term community is used to mean common to all members of that specific district. In contrast, transhumant and settled farmers are used here as individuals i.e., they own the plants individually in their closure areas, farm borders, and living fences.

\section{Wild edible plants for human food and multistage preference ranking}

Transhumants and settled farmers have shown similar preferences for WEPs $(P>0.05)$ except for $Z$. spina-christi and $G$. vilosa which differed significantly $(P<0.05)$. Settled farmers have a preference for $Z$. spina-christi and transhumants prefer $G$. villosa for human consumption (Table 14). This was confirmed by pair wise ranking with values scaled from zero to five given by informants during interviews. By this technique, the five most preferred WEPs have been prioritized and confirmed. The results can be an indicator of priority species to be integrated into dryland agrobiodiversity and agroforestry. The results provide a baseline for domestication action to sustain their utilization and conserve WEPs.

\section{Preference of wild edible plants based as food based on their taste}

Multistage direct matrix preference ranking of 14 informants from 6 study sites (14 each) $(\mathrm{N}=14 \times 6=84)$ ranked $Z$. spina-christi (first), $X$. americana (second) and $B$. dis-

Table 12. Current understanding of use \& management of wild edible plants (WEPs) by transhumants and settled farmers in two districts of East Shewa, Ethiopia. $\left(\mathrm{N}=120, \mathrm{X}^{2}=0.00\right)$. Two options: A) Traditional use \& management is more efficient than modern knowledge; B) Local people no longer employ indigenous knowledge for use and management of WEPs.

\begin{tabular}{|r|c|c|c|c|c|c|}
\hline Alternatives & \multicolumn{3}{|c|}{ A } & \multicolumn{3}{c|}{ B } \\
\cline { 2 - 7 } & Boosat & Fantalle & Total & Boosat & Fantalle & Total \\
\hline Agree & 11 & 0 & $11(9.2 \%)$ & 0 & 0 & $0(0 \%)$ \\
\hline Disagree & 49 & 60 & $109(90.8 \%)$ & 60 & 60 & $120(100 \%)$ \\
\hline Total & 60 & 60 & 120 & 60 & 60 & 120 \\
\hline
\end{tabular}


Table 13. Trends of ownership of wild edible plants (WEPs) in two districts of East Shewa, Ethiopia.

\begin{tabular}{|c|c|c|c|c|c|c|}
\hline WEP Species & & & $\begin{array}{l}\text { Commu- } \\
\text { nity }\end{array}$ & $\begin{array}{l}\text { Trans- } \\
\text { humants }\end{array}$ & $\begin{array}{l}\text { Settled } \\
\text { farmers }\end{array}$ & Total \\
\hline Balanites aegyptiacus (L.) Delile & \multirow[t]{2}{*}{ Boosat } & Count & 12 & 0 & 48 & 60 \\
\hline \multirow[t]{5}{*}{$x^{2}=79.159, d f=2, p=0.000$} & & $\%$ of Total & 10 & 0 & 40 & 50 \\
\hline & \multirow[t]{2}{*}{ Fantalle } & Count & 40 & 19 & 1 & 60 \\
\hline & & $\%$ of Total & & & & \\
\hline & \multirow[t]{2}{*}{ Total } & Count & 52 & 19 & 49 & 120 \\
\hline & & $\%$ of Total & & & & \\
\hline Berchemia discolor (Klotzsch) Hemsl. & \multirow[t]{2}{*}{ Boosat } & Count & 46 & 0 & 14 & 60 \\
\hline $29.762, \mathrm{df}=2, \mathrm{p}=0.000$ & & $\%$ of Total & 38.3 & 0 & 11.7 & 50 \\
\hline Grewia flavescens Juss. & \multirow[t]{2}{*}{ Boosat } & Count & 60 & 0 & 0 & 60 \\
\hline \multirow[t]{5}{*}{$x^{2}=3.077, d f=2, p=0.215$} & & $\%$ of Total & 50 & 0 & 0 & 50 \\
\hline & \multirow[t]{2}{*}{ Fantalle } & Count & 57 & 2 & 1 & 60 \\
\hline & & $\%$ of Total & 47.5 & 1.7 & 0.8 & 50 \\
\hline & \multirow[t]{2}{*}{ Total } & Count & 117 & 2 & 1 & 120 \\
\hline & & $\%$ of Total & & & & \\
\hline Grewia villosa Willd. & \multirow[t]{2}{*}{ Boosat } & Count & 59 & 1 & 60 & 120 \\
\hline \multirow[t]{5}{*}{$x^{2}=1.008, d f=1, p=1.000$} & & $\%$ of Total & 49.2 & 0.8 & 50 & \\
\hline & \multirow[t]{2}{*}{ Fantalle } & Count & 60 & 0 & 60 & 120 \\
\hline & & $\%$ of Total & 50 & 0 & 50 & \\
\hline & \multirow[t]{2}{*}{ Total } & Count & 119 & 1 & & 120 \\
\hline & & $\%$ of Total & & & & \\
\hline Premna resinosa (Hochst.) Schauer & \multirow[t]{2}{*}{ Boosat } & Count & 59 & 0 & 1 & 60 \\
\hline \multirow[t]{5}{*}{$x^{2}=18.510, d f=2, p=0.000$} & & $\%$ of Total & 49.2 & 0 & .8 & 50 \\
\hline & \multirow[t]{2}{*}{ Fantalle } & Count & 43 & 16 & 1 & 60 \\
\hline & & $\%$ of Total & 35.8 & 13.3 & 0.8 & 50 \\
\hline & \multirow[t]{2}{*}{ Total } & Count & 102 & 16 & 2 & 120 \\
\hline & & $\%$ of Total & 85 & 13.3 & 1.7 & 100 \\
\hline Ximenia americana $\mathrm{L}$. & \multirow[t]{2}{*}{ Boosat } & Count & 43 & 0 & 17 & 60 \\
\hline \multirow[t]{5}{*}{$x^{2}=28.391, d f=2, p=0.000$} & & $\%$ of Total & 35.8 & 0 & 14.2 & 50 \\
\hline & \multirow[t]{2}{*}{ Fantalle } & Count & 49 & 11 & 0 & 60 \\
\hline & & $\%$ of Total & 40.8 & 9.2 & 0 & 50 \\
\hline & \multirow[t]{2}{*}{ Total } & Count & 92 & 11 & 17 & 120 \\
\hline & & $\%$ of Total & 76.7 & 9.2 & 14.2 & 100 \\
\hline Ziziphus spina-christi (L.) Desf. & \multirow[t]{2}{*}{ Boosat } & Count & 3 & 0 & 57 & 60 \\
\hline \multirow[t]{5}{*}{$x^{2}=101.3, d f=2, p=0.000$} & & $\%$ of Total & 2.5 & 0 & 47.5 & 50 \\
\hline & \multirow[t]{2}{*}{ Fantalle } & Count & 32 & 26 & 2 & 60 \\
\hline & & $\%$ of Total & 26.7 & 21.7 & 1.7 & 50 \\
\hline & \multirow[t]{2}{*}{ Total } & Count & 35 & 26 & 59 & 120 \\
\hline & & $\%$ of Total & 29.2 & 21.7 & 49.2 & 100 \\
\hline Total & & Count & 119 & 1 & 120 & \\
\hline & & $\%$ of Total & 99.2 & 0.8 & 100 & \\
\hline
\end{tabular}




\section{Feyssa et al. - Comparative Analysis of Indigenous Knowledge on Use and Management of Wild Edible Plants: The case of Central East Shewa, Ethiopia}

Table 14. Preference ranking of WEPs for household food . *Significant at $p=0.05$.

\begin{tabular}{|l|c|c|c|c|c|c|c|}
\hline \multirow{2}{*}{ Preferred WEP } & \multicolumn{3}{|c|}{ Respondents } & \multicolumn{4}{|c|}{} \\
\cline { 2 - 8 } & Boosat & Fantalle & Total & Rank & Mean & $\mathbf{x}$ & $\mathbf{p}$ \\
\hline Ziziphus spina-christi (L.) Desf. & 53 & 44 & 97 & $1^{\text {st }}$ & $0.81 \pm 0.04$ & 4.36 & $0.04^{*}$ \\
\hline Balanites aegyptiacus (L.) Delile & 31 & 37 & 68 & $2^{\text {nd }}$ & $0.57 \pm 0.05$ & 1.22 & 0.27 \\
\hline Ximenia americana L. & 37 & 29 & 66 & $3^{\text {rd }}$ & $0.55 \pm 0.05$ & 2.16 & 0.14 \\
\hline Berchemia discolor (Klotzsch) Hemsl. & 28 & 36 & 64 & $4^{\text {th }}$ & $0.53 \pm 0.05$ & 1.21 & 0.27 \\
\hline Grewia flavescens Juss. & 32 & 28 & 60 & $5^{\text {th }}$ & $0.50 \pm 0.05$ & 1.20 & 0.27 \\
\hline Grewia villosa Willd. & 21 & 33 & 54 & $6^{\text {th }}$ & $0.45 \pm 0.05$ & 4.85 & $0.03^{*}$ \\
\hline Grewia tenax (Forssk.) Fiori & 23 & 25 & 48 & $7^{\text {th }}$ & $0.40 \pm 0.05$ & 0.14 & 0.71 \\
\hline Acacia senegal (L.) Willd. & 22 & 31 & 53 & $8^{\text {th }}$ & $0.44 \pm 0.05$ & 2.74 & 0.10 \\
\hline
\end{tabular}

color (third) for potential food priority. This was based on criteria set by each community (Table 15). Despite its preference based on food taste, $X$. americana was rarely encountered in the study districts. Grewia tenax (Forssk.) Fiori was in greater abundance than $X$. americana. This information can be helpful for future management actions in rehabilitation and mass cultivation of less common species.

\section{Discussion}

\section{People's perception and status of wild edible plants gathering and consumption}

The diversity of indigenous knowledge and WEP habitats promote WEP use and management in natural habitats. Balmie and Kebebew (2006) reported that $62.1 \%$ of 66 WEPs they documented in southern Ethiopia are collected from wild habitats such as wooded grasslands. Asfaw (2009) also explained that the diversity the WEPs increases as intensity of wilderness increases. The knowledge about their habitat distribution was one of the undocumented gaps in planning and sustainable utilization, pri- oritization and conservation for further promotion. The use of the documented IK is a contribution to people's assets. Łucza (2011) has reported the essential nature of emic knowledge. Teketay and Eshete (2004) and Asfaw (2006) have explained the unexploited potential of WEPs. However; the present study has revealed that, there are clear preferences of wild edible fruits by people (Table 15). The preferences are not superficial decisions but rather time tested decisions about WEPs that are preferred. Studies from other parts of world are evidence that WEPs are part of food systems of rural people (Bhattacharjee 2006). Some wild species such as $B$. aegypticus, Dobera glabra (Forssk.) Poir. and B. discolor were historically and currently still gathered, including plants consumed in all study areas with a high number of uses. They were the most important species in each use-category (fruit, medicine, forage and fuel, and construction material).

Comparative analysis of data gathered from transhumant and settled farmers indicates that patterns of WEP use appear to depend mainly on sociocultural factors followed by biophysical ones such as climate or richness of the wild edible flora. Availability of other food sources, abun-

Table 15. Average pooled summary of values of wild edible plants (WEPs) preference based on food taste as perceived by informants $(1-14)$ in two districts of East Shewa, Ethiopia, $(N=14 \times 6=84)$, values scaled $0-5(5=$ best $\& 1=$ least $)$, $14 \times 5=70$.

\begin{tabular}{|c|c|c|c|c|c|c|c|c|c|c|c|c|c|c|c|c|}
\hline \multirow[b]{2}{*}{ WEP } & \multicolumn{14}{|c|}{ Key respondents (informants) pair wise ranking } & \multirow[b]{2}{*}{ Avg } & \multirow[b]{2}{*}{ Rank } \\
\hline & 1 & 2 & 3 & 4 & 5 & 6 & 7 & 8 & 9 & 10 & 11 & 12 & 13 & 14 & & \\
\hline $\begin{array}{l}\text { Ziziphus spina-christi (L.) } \\
\text { Desf. }\end{array}$ & 5 & 4.8 & 4.5 & 4.7 & 4.8 & 4.8 & 5 & 5 & 4.8 & 4.8 & 5 & 4.8 & 5 & 4.7 & 67.8 & $1^{\text {st }}$ \\
\hline Ximenia americana L. & 4.8 & 5 & 4.8 & 4 & 4.8 & 4.5 & 4.7 & 4.8 & 4.3 & 5 & 4.2 & 4 & 4.8 & 4.3 & 64.2 & $2^{\text {nd }}$ \\
\hline $\begin{array}{l}\text { Berchemia discolor } \\
\text { (Klotzsch) Hemsl. }\end{array}$ & 4.7 & 4.2 & 4.5 & 4.2 & 4 & 4.3 & 4.5 & 4 & 4.2 & 4.3 & 4.8 & 4.2 & 4.8 & 4.2 & 60.8 & $3^{\text {rd }}$ \\
\hline $\begin{array}{l}\text { Balanites aegyptiacus (L.) } \\
\text { Delile }\end{array}$ & 4 & 4 & 4.2 & 4.2 & 4.2 & 4.2 & 3.8 & 4.7 & 4.8 & 4.7 & 3.8 & 3.7 & 4.2 & 4 & 58.3 & $4^{\text {th }}$ \\
\hline $\begin{array}{l}\text { Grewia tenax (Forssk.) } \\
\text { Fiori }\end{array}$ & 4.3 & 3.5 & 3.8 & 3 & 4.2 & 3.7 & 3.8 & 4 & 3.6 & 3.8 & 3 & 2.8 & 3.7 & 3.3 & 50.7 & $5^{\text {th }}$ \\
\hline Grewia villosa Willd. & 3.3 & 3.8 & 3.5 & 3.7 & 4.2 & 3.5 & 4.2 & 3.8 & 3.3 & 3.3 & 4 & 3.3 & 3.5 & 2.8 & 50.3 & $6^{\text {th }}$ \\
\hline Grewia flavescens Juss. & 3 & 3 & 3.5 & 3.3 & 3.5 & 3.5 & 3.5 & 2.7 & 2.3 & 3 & 3.5 & 2.5 & 3 & 2.5 & 42.8 & $7^{\text {th }}$ \\
\hline
\end{tabular}


dance of WEPs at nearby habitats, free time to collect, better communications and information exchange, direct contact with nature in everyday life, cultural values, fads (behavior) and taste preferences were some of the factors that influence why wild plants are either consumed or rejected. Few individuals in Fantalle and Boosat districts have a tendency of perceiving WEP gathering as old fashioned, unprofitable, or too time-consuming. Cultivated plants or bought food are preferentially consumed. Changes in the way rural people live in Fantalle and Boosat parallel changing knowledge and customs related to the (sustainable) utilization and management of wild resources including WEPs.

\section{Current trends of traditional use and management of wild edible plants in the study area}

Traditional rules, regulations and cultural practices are under threat due to changes of life style and education system (now generally ignoring pastoral lifestyles) in an attempt to settle transhumants. These are associated with population pressure and land use changes such as crop cultivation, increased demand for settlement and restrictions to pastoral mobility. Conflicts revolve around resource uses between pastoralists and neighboring settled farmers, e.g., commercial charcoal production in rural areas of East Shewa to generate income for households. Climate variability and climate change accelerate changes in lifestyles and have led to resource use conflict within and between communities (Tadege 2007). Pastoralists need vegetation for livestock production while urban dwellers and settled farmers use vegetation as sources of marketable fuel wood. This is a challenge to management intervention to save WEPs, natural vegetation and associated knowledge.

Maintaining pastoralists IK by enhancing awareness of useful trees such as WEPs with other uses such as forage, medicine for humans and livestock, and environmental services is one way of reducing the problem to some extent. Tables 4-7 illustrate existence of IK among transhumants and settled farmers for managing use of WEPs. Gamado-Dalle et al. (2005) have reported on the IK of Borena pastoralists using resources including WEPs. The same work has pointed out a need to integrate IK with conventional knowledge for sustainable use of resources. Hence, silvopastoral, dryland agroforestry of useful trees and shrubs is a practice to be promoted. Within the Oromiya National Regional State, Ethiopia has already initiated large-scale irrigation projects that are changing pastoral land to agriculture along with minimizing the mobility of transhumants. Promoting integrated production systems is an alternative including silvopastoral practice and dryland agroforestry in Fantalle and Boosat. Along with this, improving land productivity is an essential component to halt further deforestation of Acacia woodlands that are sources of livelihood for people of East Shewa.

\section{Storage /storability and postharvest handling of wild edible plants in the study area}

People collect WEPs and consume them immediately. Exceptions are Z. spina-christi and Tamarindus indica L. which can be stored for more than a month. Balemie and Kebebew (2009) reported that there are no storage facilities for WEPs. People gather and consume them immediately. This is also true for the present study except that some people temporally store in clay pots and plastic containers to take to market for income. Therefore, post harvest handling is a serious concern with local people requesting appropriate technologies.

\section{Gender participation in wild edible plant gathering}

Interviews showed that females have diverse knowledge and practice of use and management of WEPs. This is because they are responsible for most family food/nutrition and primary health care. Had more female informants been involved in this project, more diverse knowledge might have been documented. However, knowledge of females relating to WEPs was not thoroughly documented in the present study because of denial of permission by their husbands who were following traditional rules and norms of the communities.

\section{Traditional manipulation practices to collect wild edible plants}

The most commonly used manipulation of WEPs was the cutting fruits and seeds. The implication is that communities probably use sustainable techniques. People of the study area used various traditional methods of collecting WEPs while protecting resources from damage. Transhumants use fruits, branches and leaves. The gada system (a traditional sociopolitical institution of Oromo people) also prohibits destruction of live trees and forests. The contribution of gada is similar with that of Borena pastoralists in caring for natural vegetation (Gamado-Dalle et al. 2005). However, gada is under erosion with time. A majority of the settled farmers use vegetation both for human and livestock feed and commercial fuel wood collection. Hence, deforestation by cutting of trees and shrubs is more intensive in Boosat than Fantalle district. The house type that settled farmers construct is also more wood consuming than that of transhumant houses.

\section{Strategies of preventing threats to wild edible plants}

Tables 4-7 indicate that prevention of threats to WEPs rotates around sustainable utilization of resources through protecting habitats of WEPs. This was also noted in early studies of Asfaw (2009). A comparison of knowledge about strategies preventing threats to WEPs reveals that implementation through valuing IK practices and provision of alternative livelihoods are not significantly different $(P>0.05)$ between the study communities. However, prevention of threats through awareness raising and par- 


\section{Feyssa et al. - Comparative Analysis of Indigenous Knowledge on Use and Management of Wild Edible Plants: The case of Central East Shewa, Ethiopia}

ticipatory planning of implementation of projects is significantly different $(P<0.05)$ between the study communities. This implies the presence of diverse local knowledge and practices which can be used for further development. There is therefore need to consider the heterogeneity of IK practices in planning for conservation and sustainable use strategies. This may be done through integration of traditional and modern practices.

\section{Conservation measures practiced}

Respondents explained that, formal conservation activities practiced under current conditions cannot exceed the extremes of local traditional practices. The traditional conservation practice may or may not maintain vegetation and WEP species. Hence, there is a need to integrate formal and traditional practices to save vegetation and WEPs.

Transhumants recommended reduction of deforestation and protection of vegetation as the most important conservation practices (Table 10). However, settled farmers recommended traditional agroforestry practices. Policy intervention supporting traditional knowledge and practices therefore needs to account for differences in knowledge and technologies that are already recommended by different populations.

\section{Ownership and status of wild edible plants}

The fact that most WEPs are owned commonly has led them to decline (Hardin 1968). Gemedo-Dalle et al. (2005) and Teklehaymanot and Giday (2010) have also documented the there is a common ownership threat to WEPs. Ownership is clearly related to declining status of WEPs from the natural habitats.

\section{Traditional management of wild edible plants and natural resources}

Karrayu transhumants have customary rules, regulations and beliefs guided by the gada system to regulate resources use and management including livestock forage and local vegetation components such as medicinal plants and WEPs. Resource management through indigenous laws were probably more sustainable than a top down imposed system of controlling overharvesting or destructive practices (Balemie et al. 2004, Maundu et al. 1999). IK is intricately linked with such cultural practices including rational utilization of natural resources. This is similar to Borena pastoralists of Ethiopia, and Maasai and Borena of Kenya (Gemedo-Dalle et al. 2005). Transhumant understanding of traditional grazing management practices are firm foundations for development of sustainable resource utilization by Karrayyu transhumants.

Leonti et al. (2006) and Pardo-de-Santayana (2007) explained that elderly people are reservoirs of indigenous use and management practices of WEPs. In a similar fashion, the appointed elders from Baso and Dulacha subclans of Karrayu provide informal rules for patterns of plant resource use. Strategies used include herd diversification, and livestock mobility/rotational grazing of vegetation by livestock. This enables the herders to feed their stock on different browse and grass species and provide rest and regeneration time to grazing lands. It also enhances good ground cover in pastures, during all seasons. In early times, cutting of trees particularly for charcoal was also totally prohibited by the gada system. In past years felling of useful trees was a rare practice. It needed prior permission from clan chiefs. This practice promoted sustainable utilization of vegetation resources, livestock, and their products. Transhumants use sticks to shake down tree and shrub leaves, seeds and pods (rather than cutting the plants). These plant parts are used for livestock forage. These practices sustain biodiversity and its utilization for production of WEPs and livestock forage thereby promoting livestock products and enhanced food security. Similar observations were reported among Afar pastoralists of Ethiopia (Simonsen 1996).

Knowledge of use and management of natural resources and WEPs of settled farmers differed from transhumants. These include strong cultural practices that protect trees and limit commercial fuel wood production. Comparatively intensive expansion of agricultural land coupled with intensive roadside settlement has devastated the vegetation of areas of settled farmers. Among the good practices observed in both transhumant and settled farmer areas were conserving WEPs such as $B$. aegyptiacus, $Z$. spinachristi, B. discolor, Premna resinosa (Hochst.) Schauer in living fences, dryland agroforestry, and farm borders.

\section{Transfer of knowledge associated with wild edible plants in Boosat and Fantalle}

Knowledge associated with use of WEPs is generally in the public domain of both transhumants and settled farmers. Each has direct and indirect ways of transferring knowledge to the next generation and for exchange with each other. Table 8 illustrates the strong responsibility of the public in transferring and maintaining IK across generations. The knowledge flow from elders to children and its enrichment thereafter is directly conveyed through observation, imitation, and free flow of information among community members through history telling and myths. Balemie and Kebebew (2006) reported that elder community members are the reservoirs of wild plants use in southern Ethiopia. Songs, riddles, and sayings in East Shewa are indirect ways of conveying knowledge. The knowledge conveyed includes, plant identification, edible parts, tastes, and unwanted effects. Knowledge also includes preferences and social strata particularly interested in consumption of specific WEPs. Folklore is used for comprehensive description of WEPs, nomenclature, morphology, habit and habitat, plant use during traditional ceremo- 
nies, use diversity, abundance and preference for specific uses. Asfaw (2009) has described that local people have knowledge and skills to identify food and medicinal plants.

\section{Dynamics of indigenous knowledge on wild edible plants}

There is variation in level of IK of WEPs and other natural resources (Table 9). The dynamicity of ethnobotanical knowledge, changing with vegetation and life style of people is specific to each community. Resource use in general and local people's use and management of resources changes with natural environmental and sociocultural dynamics (Asfaw 1997, Balemie \& Kebebew 2006, Cotton 1996). Key informants pointed out a number of reasons for changes in use and management of WEPs including increased human population. In the process of coping with a changing environment, new knowledge comes and replaces some existing knowledge (Maundu et al. 1999). This may be a threat to local IK through access to global biocultural wealth.

\section{Preferences for wild edible plants and prioritization of species for dryland agrobiodiversity}

WEP preference is different between transhumants and settled farmers (Tables 14, 15). This differs from the results of Balemie and Kebebew (2006) where there was no difference between communities and their preference for WEPs. However, they found variation in responses depended on nutritional value, taste, and ease of processing. Differences in life styles between transhumanants and settled farmers is thought to result in differences in their IK about WEPs. Harnessing this variation of knowledge to sustainably utilize natural resources would be an opportunity to adapt to climate change in fragile ecosystems. Teklehaymanot and Giday (2010) emphasized the utilization of IK of preferred WEPs for further nutritional and toxicity studies. This supports the current study in recommending further studies for sustainable utilization of both WEPs and associated IK. The prioritization of WEPs may be a basis for further socioeconomic work on crop domestication, intercropping, and integrated livestock production.

\section{Sustainable use of wild edible plants}

The Millennium Development Goals focus on the linkages between ecosystem services and human well being (Johns \& Eyzaguirre 2002). Biodiversity and ecosystems have intrinsic value and that people need to consider when making management decisions (Asfaw 2009, Ladio \& Lozada 2004, Ladio et al. 2006). Conservation of a resource is intricately associated to its uses for human well being. Agrobiodiversity, WEPs and IK systems if maintained in sustainable ways can contribute to wider ecosystem functions, and serve as refugia for species during droughts. Therefore, comprehensive studies need to be done to sustainably use these species rather than relying only on agricultural crop products. The need for adaptations to climate change and improved use of WEPs requires conservation of diverse genetic resources both in-situ and ex-situ.

Most of the WEPs were not domesticated or cultivated. People do take care to maintain strains of WEPs which they did not cultivate. Their growth has been tolerated or encouraged on the edges of fields, near gardens, or in the bush, in a semi-domesticated manner. People of East Shewa also take specimens with them when they change their settlements. This practical, time tested knowledge needs to be integrated with conventional knowledge to promote sustainable use and management of WEPs.

\section{Conclusions}

The present results show the need for social marketing and nutritional education in order to achieve sustainable WEPs consumption and management. Creating a value chain with appropriate technologies adding alternative value to edible parts of WEPs is an important issue. Equally important is valuing and maintaining diverse IK. This should be explored through research and policy agenda. Integrating traditional use and management of, and IK about, WEPs with modern management should be urgently supported through extension services and modern technologies.

\section{Acknowledgments}

We thank people of Fantalle and Boosat districts who gave information on the uses and management of plants. We thank the entire administrative structure of East Shewa Zone for facilitating the fieldwork. The Regional Universities Forum for Capacity Building in Agriculture (RUFORUM), RUFORUM-IDRC, The Rockefeller Foundation, and the Association of African Universities (AAU) are thankfully appreciated for funding the research. Unreserved support and contributions of University of Nairobi, CAVS, LARMAT, and Kenya for hosting and administrative support and Jimma University, College of Agriculture and Veterinary Medicine, Ethiopia for providing research and ICT facilities and field vehicles are also thankfully acknowledged.

\section{Literature Cited}

Addis, G., K. Urga \& D. Dikasso. 2005. Ethnobotanical study of edible wild plants in some selected districts of Ethiopia. Journal of Human Ecology 33(1):83-118.

Asfaw, Z. 1997. Indigenous African Food Crops and Useful Plants: Survey of indigenous food crops, their preparations and home gardens. The United Nations University 


\section{Feyssa et al. - Comparative Analysis of Indigenous Knowledge on Use and Management of Wild Edible Plants: The case of Central East Shewa, Ethiopia}

Institute for Natural Resources in Africa. ICIPE Science Press, Nairobi.

Asfaw, Z. 2006. Towards a dynamic indigenous knowledge practice: Optimization of the use and management of plant resources in drylands of Ethiopia. Pp.64-71 in Drylands Ecosystems: Challenges and opportunities for sustainable natural resources management. Edited by A.M. Nikundiwe \& J.D.I. Kabigumila. Proceeding of the Regional Workshop June 7-9, held at Hotel Impala, Arusha, Tanzania.

Asfaw, Z. 2009. The future of wild food plants in Southern Ethiopia ecosystem conservation coupled with management of the roles of key social groups. Pp. 86-87 in International Symposium on Underutilized Plants for Food Security, Nutrition, Income and Sustainable Development. Edited bu H. Jaenicke, J. Ganry, I. Hoeschle-Zeldon \& R. Kahane. International Society for Horticultural Science, Arusha, Tanzania.

Balemie, K. \& F. Kebebew. 2006. Ethnobotanical study of wild edible plants in Derashe and Kucha Districts, South Ethiopia. Journal of Ethnobotany and Ethnomedicine 2(53):1-9.

Bhattacharjee, L. 2006. Indigenous peoples' food systems for health: Finding interventions that work. Public Health and Nutrition 9:1013-1019.

Cotton, C.M. 1996. Ethnobotany: Principles and applications. John Wiley and Sons Ltd., New York, New York.

Demissew, D \& I. Firiis. 2009. Natural vegetation of the flora. Pp. 27-32 in Flora of Ethiopia and Eriteria. Volume 8. General part and Index to Vol 1-7. Edited by I. Hedberg, I. Friis. \& E. Persson. National Herbarium, Biology Department of Systematic Botany, Uppsala University, Uppsala, Sweden.

FDFED. 2009. Socioeconomic Profile of Fantalle District. Fantalle District Finance \& Economic Development (FDFED). East Shewa, Fantalle.

Garcia, G.C. 2007. Biodiversity, Poverty and Hunger. UNESCO-L'OREAL for Women in Science Fellow 2007 the Netherlands. www.agora.com.

Gemedo-Dalle, T., B.L. Maass \& J. Isselstein. 2005. Plant biodiversity and ethnobotany of Borena pastoralists in Southern Oromia, Ethiopia. Economic Botany 59(1):4365.

Guinad, Y. \& D. Lemessa. 2000. Wild Food Plants in Southern Ethiopia: Reflection on the role of famine foods at a time of drought. University of Pennsylvania African Studies Center. www.africa.upenn.edu, (Accessed 20 June, 2009).
Hardin, G. 1968. The tragedy of the commons. Science 162(3859):1243-1248.

Höft, M., S.K. Barik \& A.M. Lykke. 1999. Quantitative Ethnobotany. Applications of multivariate and statistical analyses in ethnobotany. People and Plant Working Paper; Pp.1-50.

IIRR. 1996. Recording and Using Indigenous Knowledge: A manual. International Institute of Rural Reconstruction, Silang, Cavite, Philippines.

Johns, T. \& P.B. Eyzaguirre. 2002. Nutrition and Environment. Pp. 1-4 in Nutrition: $A$ foundation for development. Administrative Committee on Coordination/Sub-Committee on Nutrition, Geneva.

Kent, M. \& P. Coker. 1992. Vegetation Description and Analysis - A practical approach. John Wiley \& Sons, Ltd. London.

Knapp, C.N. \& M.E. Fernandez-Gimenez. 2009. Understanding change: Integrating rancher knowledge into state-and-transition models. Rangeland Ecological Management 62:510-521.

Ladio, A., M. Lozada \& M. Weigandt. 2007. Comparison of traditional wild plant knowledge between aboriginal communities inhabiting arid and forest environments in Patagonia, Argentina. Journal of Arid Environments 69:695715.

Ladio, A.H. \& M. Lozada. 2004. Comparison of wild edible plant diversity and foraging strategies in two aboriginal communities of northwestern Patagonia. Biodiversity and Conservation 12:937-951.

Leonti, M., S. Nebel, D. Rivera \& M. Heinrich. 2006. Wild gathered food plants in the European Mediterranean: A comparative analysis. Economic Botany 60:130-142.

Łucza, L. 2011. Herbal bouquets blessed on assumption day in South-Eastern Poland: Freelisting versus photographic inventory. Ethnobotany Research \& Applications 9:001-025.

Maffi, L. 2005. Linguistic, cultutral and biological diversity. Annual Review of Anthropology 34:599-617.

Maundu, P.M., G.W. Ngugi \& C.H.S. Kabuye. 1999: Traditional Food Plants of Kenya. National Museums of Kenya Press, Nairobi.

Marsden, S.J. \& J.D. Pilgrim. 2003. Diversity and abundance of fruiting trees in primary forest, selectively logged forest, and gardens on New Britain, Papua New Guinea. Tropical Biodiversity 8(1):15-29. 
Martin, G.J. 1995. Ethnobotany: A methods manual. Chapman and Hall, London.

Mathys, E. 2000. Assessment of the Impact of Food Aid on Household Economics of North Wollo, South Wollo and East Hararghe, Ethiopia. Food Security Unit, Save the Children (U.K.), Nairobi.

Pardo-de-Santayana, M., J. Javier Tardío, E. Blanco, M. Carvalho, J.J. Lastra, E.S. Miguel \& R. Morales. 2007. Traditional knowledge of wild edible plants used in the northwest of the Iberian Peninsula (Spain and Portugal): A comparative study. Journal of Ethnobiology and Ethnomedicine 3:27.

Redzic, S.J. 2006. Wild edible plants and their traditional use in the human nutrition in Bosnia-Herzegovina. Ecology of Food and Nutrition 45:189-232.

Schery, R.W. 1972. Plants for Man. Prentice Hall, Englewood Cliffs, New Jersey.

Simonsen, G. 1996. A Study of Natural Resource Management of Pastoral in Northeastern Ethiopia. M.Sc. thesis. Universitetet for Miljø- Og Biovitenskap, Aas, Norway.

Taddesse, W. \& S. Alem. 2009. The Role and Status of Selected Wild Edible Fruit Trees in Rural Livelihood of Ethiopia. Institute of Agriculture Research, Addis Ababa.

Tadege, A. 2007. Editor of Climate Change National Adaptation Programme of Action (NAPA) of Ethiopia. Ministry of Water Resources, National Meteorological Agency, Addis Ababa.
Tardío, J., M. Pardo-de-Santayana \& R. Morales. 2006. Ethnobotanical review of wild edible plants in Spain. Botanical Journal of the Linnean Society 152:27-71.

Tauli-Corpuz, V. 2010. The importance of indigenous peoples in biodiversity conservation. Environment Matters 2010:6-7.

Teketay, D. \& A. Eshete. 2004. Status of indigenous fruits in Ethiopia. Pp. 2-35 in Review and Appraisal on the Status of Indigenous Fruits in Eastern Africa: A report prepared for IPGRI-SAFORGEN in the framework of AFRENA/FORENESSA. Edited by B. Chikamai, O. Eyog-Matig \& M. Mbogga. Kenya Forestry Research Institute, Nairobi.

Teklehaymanot, T. \& M. Giday. 2010. Ethnobotanical study of wild edible plants of Kara and Kwego semi-pastoralist people in Lower Omo River Valley, Debub Omo Zone, SNNPR, Ethiopia. Journal of Ethnobiology and Ethnomedicine 6:23.

Warren, D.M. 1992. Indigenous knowledge, biodiversity conservation and development. Pp. 1-12 in International Conference on Conservation of Biodiversity in Africa: Local initiatives and institutional roles, 30 August-3 September. Nairobi.

Warren, D.M. 1997. Conservation of indigenous knowledge serves conservation of biodiversity. Alternatives Journal 23(3).

White, F. 1983. The Vegetation of Africa: A descriptive memoir to accompany the UNESCO/AETFAT/UNSO vegetation map of Africa. UNESCO, Paris. 